\title{
'Turkish students' computer self-efficacy from colleges of physical education and sports
}

\author{
Iş1 Aktağ ${ }^{1}$ \\ Soner Tuzcuoğlu ${ }^{2}$
}

\begin{abstract}
The purpose of this research was to determine computer self-efficacy, performance outcome, personal outcome, affective outcome and anxiety level of physical education teacher candidates. Also influence of computer usage and taking computer course on computer self-efficacy level were determined too. The subjects of this study were physical education teacher candidates from 3 universities with a total of 452. Data were collected by survey which was developed by Compeau and Higgins in 1995 and translated to Turkish by researcher. The results of the study showed that there was no significant difference between male and female students in their computer selfefficacy, performance outcome, personal outcome and affective outcome but significant difference was found in their anxiety level with female students had lower anxiety level than male students. This study showed that as the duration and frequency of computer usage increases, students' computer self-efficacy increases too.
\end{abstract}

Keywords: Computer Self-Efficacy; Anxiety; Gender; Physical Education Teacher Candidates.

\section{Introduction}

Technology plays an important role in the development of education and it changes very fast from day to day. In order to follow changes in technology, Turkish higher education program offers to university students mandatory technology course to help them become more knowledgeable in basic concepts of technology and to improve some basic computer skills such as word processor, Internet usage, power point, data base, etc. Physical education and teaching has a quite different nature of its' teaching, learning and organization of course. Although it might be seen that the area of sport would be the last place where technology especially computer would be used, individuals who teach, coach and manage people in the world of sport expected to use office automation software to prepare lesson plans, assignments to store, recording process about players, use Internet for advocacy and communication with parents and students-players and for their own professional development (Papastergiou, 2010, p:299) But simply teaching technology course at schools doesn't guarantees that individuals use it in their every aspect of daily life. (Tezci, 2011 as cited in OECD, 2004). In addition to access, psychological and organizational factors play a critical role in the Information Communication Technology integration (Stuart and et all. 2009).

\footnotetext{
1 Assistant Professor, Abant İzzet Baysal University, Physical Education Teaching Department, Bolu, Turkey, iaktag@gmail.com

${ }^{2}$ M.Sc., M.E.B., Ankara, Turkey, soner tuzcuoglu@hotmail.com
} 
Aktağ, I., \& Tuzcuoğlu, S. (2016). Turkish students' computer self-efficacy from colleges of physical education and sports. International Journal of Human Sciences, 13(1), 1770-1779. doi:10.14687/ijhs.v13i1.3606

Self-efficacy is one of these psychological factors that influence individuals' computer usage. Self-efficacy as defined by Bandura (1997) is "people's judgments of their capabilities to organize and executive courses of action required to attain designated types of performances". According to his Social Cognitive Theory (1977), self-efficacy beliefs help determine the choices people make, the persistence and perseverance they display in the face of difficulties and the degree of anxiety toward tasks in their life (Bandura, 1997). It has been proposed that individuals based self-efficacy judgments on four main sources of information (Bandura, 1997).

-Enactive mastery experience: These experiences are the most powerful source of efficacy information because they provide the most authentic evidence of whether one can muster whatever it takes to succeed. They are interpreted results of one's previous performance or mastery experience.

-Vicarious experience: Observing other persons successfully perform the actions that are contemplating, individuals think if others can accomplish tasks they tend to have the capabilities to raise their performance.

-Verbal persuasion: It involves verbal input from others that strengthen a person's belief that he or she possesses the capability to achieve a desired level of performance.

-Physiological and affective states: A person's level of arousal can influence his or her self-efficacy beliefs. Arousal such as elevated hearth and respiratory rate, trembling hands etc. are perceived as a treat.

Computer self-efficacy is based on self-efficacy beliefs. Correspondingly, computer selfefficacy refers to "a judgment of one's capability to use a computer (Compeau and Higgins, 1995).Computer self-efficacy is an important trait that influences individuals' decision to use computers. Individuals with higher computer self-efficacy beliefs tend to see themselves as able to use computer technology on the other hand; individuals with lower computer self-efficacy beliefs become more frustrated and more anxious working with computers and hesitate to use computers when they encounter obstacles (Karsten and Roth, 1998).

In this study a research study model developed by Compeau et all. (1999) was used. This model identifies the linkages between cognitive factors (self-efficacy, performance related outcome expectations and personal related outcome expectations), affective factors (affect and anxiety) and usage of computer. Self-efficacy reflects on individuals' beliefs about his-her capabilities to use computers. Outcome expectations are consequences of using computers. There are two types: performance and personal outcomes. Performance related outcomes are associated with improvements in job or school performance, personal outcome expectations relate to expectations of change in image or status or to expectations of rewards such as raises, promotions or praises. Affect and anxiety represent the affective responses of individuals toward using computers. Affect represents the positive situations, for example, the enjoyment a person get by using computers; while anxiety represents negative situations, the feelings of apprehension or anxiety that one experiences when using computers. Using computers represents the degree of use of computers at school, at work or at home.

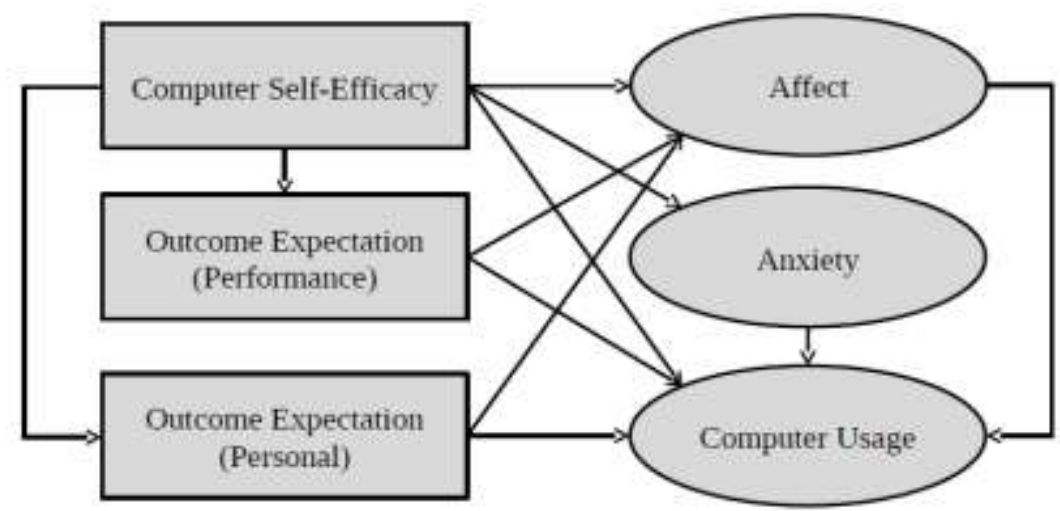

Figure 1: Link between cognitive and affective factors. 
Aktağ, I., \& Tuzcuoğlu, S. (2016). Turkish students' computer self-efficacy from colleges of physical education and sports. International Journal of Human Sciences, 13(1), 1770-1779. doi:10.14687/ijhs.v13i1.3606

model.

Specifically, this study investigated the following hypotheses related with the research

- The higher the computer self-efficacy, the higher the affect, performance and personal outcome.

- The higher the computer self-efficacy, the lower the anxiety.

- The higher the computer self-efficacy, the higher the positive influence on computer usage.

- The higher the individuals' computer anxiety, the lower his-her use of computers.

Research focused on the relationship of individual and situational factors to computer selfefficacy. One of these factors is the influence of computer experience on computer self-efficacy. Computer experience is interpreted according to the amount of time an individual has spent working with computers and the different applications they have learned to use. Research supports that there is a positive correlation between computer self-efficacy and computer experience. As individuals experience with computers, their computer self-efficacy level increases too (Saleh, 2007; Papastergiou, 2010; Koçak et all. 2003). In this study taking computer course is asked students to determine their experience with computers and also it is asked them to specify frequency and duration of computer usage in their daily life.

Computer anxiety might be a reason for not using computers effectively. Computer selfefficacy is negatively correlated with computer anxiety. Research supports that the more experience with computers, reduces the level of anxiety (Compeau et all. 1999; Simsek 2011, Korabili et.all, 2010).

The literature suggests that gender may impact the relationship between computers and user attitudes. There have been different results related with situation of males and females. According to some researches, males have more positive reactions than females toward computers (Isssman and Çelikli 2009; Durndell and Haag, 2002) while some others found no difference between males and females in their computer self-efficacy (Aktag, 2013; Ünlü and Süel, 2014, Torkzadeh, et all, 1999).

When students experience successes through completing various course activities arranged at increasing difficulty levels, they will be more likely to experience increased self-efficacy and selfconcept, which in turn, serve to improve college students' academic achievement. Students with high levels of computer self-efficacy have been found to be more willing to participate in computer related activities and to be more successful at these activities (Çolak, 2003 as cited in Akkoyunlu and Orhan, 2003). Given the importance of computers in the lives of individuals nowadays it can be reasonable that students' computer self-efficacy plays an important role in their academic successes.

\section{Methodology}

\section{Purpose of the study}

The purpose of this study is to determine the computer self-efficacy, performance outcome, personal outcome, affective outcome and anxiety level of students from College of Physical Education and Teaching at three different universities. Also influence of gender, academic GPA, taking computer course at university and computer usage on computer self-efficacy will be determined.

\section{Participants}

The participants of this study were students at College of Physical Education and Teaching from 3 different universities. These universities are Abant İzzet Baysal University, Celal Bayar University and Gaziantep University. Students were registered for spring semester in 2014-2015 and the participation was voluntary. There were total 452 participants, which 258 students from Abant İzzet Baysal University, 94 from Celal Bayar University and 100 from Gaziantep University. Computer course is required course for students in College of Physical Education and Sport. This course is designated to provide students an opportunity to develop or enhance their knowledge of and hands on facility with appropriate computer hardware and software. 
Aktağ, I., \& Tuzcuoğlu, S. (2016). Turkish students' computer self-efficacy from colleges of physical education and sports. International Journal of Human Sciences, 13(1), 1770-1779. doi:10.14687/ijhs.v13i1.3606

\section{Data Collection Instrument}

In this research Computer Efficacy Scale was used. It was developed by Compeau and Higgins in 1995. The scale contains 6 parts:

1. Computer Self-Efficacy (CSE) was measured by 10 items (instrument developed by Compeau and Higgins, 1995). Participants were asked to indicate on a 10 point scale, their ability to accomplish a task using on software package with different level of assistance. In scale, 1 represent not at all confident, while 10 represents totally confident.

2. and 3. Outcome expectations for Personal Outcome (PO) and Performance Outcome (PFO) were measured by 11 items with 5 point scale (Compeau and Higgins, 1995). In scale 1 represents very unlikely while 5 represents likely.

4. Affective Outcome (AFO) was measured by 5 items with 5 point scale (Instrument developed by Koyd and Gressard, 1984).In scale 1 represent very unlikely while 5 represent very likely.

5. Anxiety (A) was measured by 4 items (Instrument developed by Heinssen et all. 1987). In scale 1 represents very unlikely while 5 represents very likely.

6. Computer usage was measured by 3 items, reflecting the frequency of computer usage at their daily life and the duration of computer use on weekdays and weekends.

Reliability and validity of scale is determined by Aktag, 2013. In order to obtain validity of scale factor analysis was conducted. According to the results of analysis, the loading of factors were between .43 and .80 . According to this loading, scale consists of 5 factors and 28 items. 2 items in performance outcome is loaded on another factor that is why those items dropped from scale. Thus, total 28 items used from this scale. Those factors are named as Computer Self-Efficacy as CSE, Personal Outcome as PO, Anxiety as A, Affective Outcome as AFO, and Performance Outcome PFO. For the reliability of data, the Cronbach's alpha coefficient was calculated and it was found that .88 for the whole scale.

\section{Results}

Table 1: Means and S.D. of physical education students' computer self-efficacy, performance outcome, affective outcome, personal outcome and anxiety.

\begin{tabular}{lccccc}
\hline & $\mathbf{N}$ & $\overline{\mathbf{X}}$ & Min. & Max. & SD \\
\hline Performance outcome & 452 & 3.62 & 1.00 & 5.00 & .845 \\
Affective outcome & 452 & 3.59 & 1.00 & 5.00 & .738 \\
Anxiety & 452 & 1.83 & 1.00 & 5.00 & .994 \\
Computer self-efficacy & 452 & 7.24 & 1.00 & 10.00 & 2.01 \\
Personal outcome & 452 & 3.19 & 1.00 & 5.00 & 1.01 \\
\hline
\end{tabular}

In Table 1, arithmetic means of participants' Computer self-efficacy, Performance outcome, Affective outcome, Personal outcome and anxiety calculations are tabulated with their standard deviations. 
Table 2: $T$ test results of computer self-efficacy, performance outcome, affective outcome, personal outcome and anxiety due to gender.

\begin{tabular}{|c|c|c|c|c|c|c|c|}
\hline Measurements & Gender & $\mathbf{N}$ & $\overline{\mathbf{X}}$ & SD & df & $\mathrm{t}$ & $\mathrm{p}$ \\
\hline \multirow{2}{*}{$\begin{array}{l}\text { Computer } \\
\text { Self-Efficacy }\end{array}$} & Female & 174 & 7.15 & 2.10 & \multirow{2}{*}{450} & \multirow{2}{*}{-.809} & \multirow{2}{*}{.464} \\
\hline & Male & 278 & 7.30 & 1.95 & & & \\
\hline \multirow{2}{*}{$\begin{array}{l}\text { Performance } \\
\text { Outcome }\end{array}$} & Female & 174 & 3.52 & .85 & \multirow{2}{*}{450} & \multirow{2}{*}{-1.92} & \multirow{2}{*}{.756} \\
\hline & Male & 278 & 3.68 & .83 & & & \\
\hline \multirow{2}{*}{$\begin{array}{l}\text { Affective } \\
\text { Outcome }\end{array}$} & Female & 174 & 3.52 & .72 & \multirow{2}{*}{450} & \multirow{2}{*}{-1.47} & \multirow{2}{*}{.468} \\
\hline & Male & 278 & 3.63 & .74 & & & \\
\hline \multirow{2}{*}{ Anxiety } & Female & 174 & 1.78 & .90 & \multirow{2}{*}{450} & \multirow{2}{*}{-.816} & \multirow{2}{*}{$.015^{*}$} \\
\hline & Male & 278 & 1.86 & 1.04 & & & \\
\hline \multirow{2}{*}{$\begin{array}{l}\text { Personal } \\
\text { Outcome }\end{array}$} & Female & 174 & 3.20 & 1.02 & \multirow{2}{*}{450} & \multirow{2}{*}{.117} & \multirow{2}{*}{.778} \\
\hline & Male & 278 & 3.19 & 1.01 & & & \\
\hline
\end{tabular}

Table 2 represents a comparison of students' computer self-efficacy, performance outcome, affective outcome, personal outcome and anxiety according to their gender. It is found that except anxiety, there was no significant difference between male and female students in their computer self-efficacy, performance, affective and personal outcomes. The only difference between male and female students is found in their anxiety scores. Female students anxiety mean 1.78 while this was 1.86 for male students $(\mathrm{t}(452)=-.816, \mathrm{p}=.015<.05)$.

Table 3: $T$ test results of computer self-efficacy, performance outcome, affective outcome, personal outcome and anxiety due to taking computer course or not.

\begin{tabular}{|c|c|c|c|c|c|c|c|}
\hline Measurements & Course & $\mathbf{N}$ & $\overline{\mathbf{X}}$ & SD & df & $\mathbf{t}$ & $\mathrm{p}$ \\
\hline \multirow{2}{*}{$\begin{array}{l}\text { Computer } \\
\text { Self-Efficacy }\end{array}$} & Register & 305 & 7.29 & 1.91 & \multirow[b]{2}{*}{450} & \multirow[b]{2}{*}{.776} & \multirow[b]{2}{*}{.071} \\
\hline & $\begin{array}{l}\text { Not } \\
\text { register }\end{array}$ & 147 & 7.14 & 2.20 & & & \\
\hline \multirow[b]{2}{*}{$\begin{array}{l}\text { Performance } \\
\text { Outcome }\end{array}$} & Register & 305 & 3.64 & .83 & \multirow[b]{2}{*}{450} & \multirow[b]{2}{*}{.976} & \multirow[b]{2}{*}{.785} \\
\hline & $\begin{array}{l}\text { Not } \\
\text { register }\end{array}$ & 147 & 3.56 & .87 & & & \\
\hline \multirow{2}{*}{$\begin{array}{l}\text { Affective } \\
\text { Outcome }\end{array}$} & Register & 305 & 3.61 & .74 & \multirow[b]{2}{*}{450} & \multirow[b]{2}{*}{.765} & \multirow[b]{2}{*}{.483} \\
\hline & $\begin{array}{l}\text { Not } \\
\text { register }\end{array}$ & 147 & 3.55 & .72 & & & \\
\hline \multirow[b]{2}{*}{ Anxiety } & Register & 305 & 1.86 & 1.03 & \multirow[b]{2}{*}{450} & \multirow[b]{2}{*}{1.131} & \multirow[b]{2}{*}{$.045^{*}$} \\
\hline & $\begin{array}{l}\text { Not } \\
\text { register }\end{array}$ & 147 & 1.75 & .97 & & & \\
\hline \multirow[b]{2}{*}{$\begin{array}{l}\text { Personal } \\
\text { Outcome }\end{array}$} & Register & 305 & 3.26 & .98 & \multirow[b]{2}{*}{450} & \multirow[b]{2}{*}{1.959} & \multirow[b]{2}{*}{.370} \\
\hline & $\begin{array}{l}\text { Not } \\
\text { register }\end{array}$ & 147 & 3.06 & 1.06 & & & \\
\hline
\end{tabular}


When Table 3 was analyzed, only significant difference was found in anxiety scores of students whether they took computer course or not. Students who took computer course had $\bar{X}$ $=1.86$ and who did not $\bar{X}=1.75$. As seen from the results, students who took computer course had significantly higher anxiety level than students who did not.

Table 4: One way Anova results of computer self-efficacy due to frequency of computer usage.

\begin{tabular}{|c|c|c|c|c|c|c|c|}
\hline & Computer Usage & $\mathbf{N}$ & $\overline{\mathbf{X}}$ & SD & $\mathbf{F}$ & $\mathbf{P}$ & $\begin{array}{r}\text { Post Hoc } \\
\text { (Tukey) }\end{array}$ \\
\hline \multirow{6}{*}{$\begin{array}{l}\text { Computer } \\
\text { self- } \\
\text { efficacy }\end{array}$} & Never use & 9 & 5.40 & 2.47 & \multirow{6}{*}{7.17} & \multirow{6}{*}{0.00} & \multirow{6}{*}{$\begin{array}{l}1-3 \\
1-4 \\
1-5 \\
2-3 \\
2-4 \\
2-5\end{array}$} \\
\hline & $\begin{array}{l}\text { Several times a } \\
\text { month }\end{array}$ & 39 & 6.22 & 2.58 & & & \\
\hline & & & & & & & \\
\hline & $\begin{array}{l}\text { Several times a } \\
\text { week }\end{array}$ & 124 & 6.97 & 1.98 & & & \\
\hline & Several times a day & 142 & 7.55 & 1.68 & & & \\
\hline & Always use & 138 & 7.59 & 1.95 & & & \\
\hline
\end{tabular}

As seen in Table 4, about half of the students use computers frequently during the day. This shows us that students spend a lot of time spending with computers. As students spend more and more time on computers their computer self-efficacy level increases accordingly. Significant differences were found among students due to frequency of computer usage. Students who said they always use computers have the highest computer self-efficacy scores $(\bar{X}=7.59)$ while who said they never use computers have the lowest computer self-efficacy scores $(\bar{X}=5.40)$.

Table 5: One way Anova results of computer self-efficacy due to duration of computer usage during weekdays and weekends.

\begin{tabular}{|c|c|c|c|c|c|c|c|}
\hline Weekdays & Computer Usage & $\mathbf{N}$ & $\overline{\mathbf{X}}$ & SD & $\mathbf{F}$ & $\mathbf{P}$ & $\begin{array}{c}\text { Post Hoc } \\
\text { (Tukey) }\end{array}$ \\
\hline & Never use & 20 & 5.48 & 2.82 & \multirow{5}{*}{5.119} & \multirow{5}{*}{0.00} & \multirow{5}{*}{$\begin{array}{l}1-2 \\
1-3 \\
1-4 \\
1-5 \\
2-3\end{array}$} \\
\hline & Less than $30 \mathrm{~min}$. & 70 & 6.94 & 2.13 & & & \\
\hline & $30 \mathrm{~min}-2 \mathrm{hrs}$ & 141 & 7.30 & 1.93 & & & \\
\hline & 2hrs-4hrs & 109 & 7.44 & 1.80 & & & \\
\hline & More than 4 hrs & 112 & 7.48 & 1.89 & & & \\
\hline
\end{tabular}

Weekends

\begin{tabular}{|c|c|c|c|c|}
\hline Never use & 45 & 6.67 & 2.65 & \\
\hline Less than $30 \mathrm{~min}$. & 96 & 7.15 & 1.99 & \\
\hline $30 \mathrm{~min}-2 \mathrm{hrs}$ & 122 & 7.14 & 2.03 & 1.77 \\
\hline 2hrs-4hrs & 93 & 7.47 & 1.71 & \\
\hline More than $4 \mathrm{hrs}$ & 96 & 7.51 & 1.87 & \\
\hline
\end{tabular}


Table 5 shows the results of duration of computer usage of students during weekdays and weekends. 141 students said they use computers between 30min.-2 hours which is the highest time period among others. After that time period, 112 students specified they use computers more than 4 hours during weekdays. Computer self-efficacy of students increased significantly as their computer usage time increased. Higher computer self-efficacy score belongs to students who said they use computers more than 4 hours during weekdays $(\overline{\mathrm{X}}=7.48)$ and lowest computer selfefficacy score belongs to students who said they never use computers $(\bar{X}=5.48)$.

When it was look at the weekends, again there was highest number of students found in 30 min-2 hours time period that stated they use computers during weekend. Similar to the results for weekday's computer self-efficacy scores of students increased as their computer usage time increased during weekends. The highest computer self-efficacy mean belongs to students who said they use computers more than 4 hours (7.51) and the lowest computer self-efficacy mean belongs to students who said they never use (6.67). Results show us the more time students spend on computers during weekend their computer self-efficacy increased but this increasement was not significant.

Table 6: Pearson Correlation results of students who took computer course, GPA, computer self-efficacy and computer course grade.

\begin{tabular}{lccc}
\hline & \multicolumn{2}{c}{ CSE } & \multicolumn{2}{c}{$\begin{array}{c}\text { Computer Course } \\
\text { Grade }\end{array}$} \\
\hline \multirow{3}{*}{ GPA } & $\mathrm{r}$ & .102 & -.193 \\
\cline { 2 - 3 } & $\mathrm{p}$ & .075 & $.001^{*}$ \\
\cline { 2 - 3 } & $\mathrm{N}$ & 305 & 305 \\
\hline $\begin{array}{l}\text { Computer } \\
\text { Course } \\
\text { Grade }\end{array}$ & $\mathrm{r}$ & -.018 & \\
\cline { 2 - 3 } & $\mathrm{p}$ & .752 & \\
\hline
\end{tabular}

When Table 6 was analyzed, only significant correlation was found between students computer course grade and their GPA and this correlation was in negative way. $(r=-.193, p=.001$ $<$.05).It means as students GPA scores increased their computer course grade decreased. There was no significant correlation among students computer self-efficacy and computer course grade.

\section{Discussion}

In this study, a sample of 'Turkish students' from College of Physical education teaching computer self-efficacy, performance outcome, personal outcome, affective outcome and anxiety levels were investigated due to their gender, GPA, whether they took computer course and the duration of time they spend with computer.

The $t$ test results indicated that there was no significant difference in computer self-efficacy, performance outcome, personal outcome and affective outcome according to their gender. Only significant difference was found in anxiety scores between male and female students. Female students had lower anxiety scores $(\overline{\mathrm{X}}=1.78)$ than male students $(\overline{\mathrm{X}}=1.86)$. Findings regarding gender differences have been inconsistent. Some findings show that males have higher computer self-efficacy than females; other researchers reported no gender differences between males and females. Similar to results of this study, Karsten and Roth, 1998; Pamuk and Peker,2009; Teo,2008; Ünlü and Süel, 2014, found that males and females weren't different with respect to level of computer self-efficacy while İsman and Çelikli,2009; Dundell and Haag, 2002, found male students 
Aktağ, I., \& Tuzcuoğlu, S. (2016). Turkish students' computer self-efficacy from colleges of physical education and sports. International Journal of Human Sciences, 13(1), 1770-1779. doi:10.14687/ijhs.v13i1.3606

are more confident comparing to female students. The reason not to be any significant difference between female and males in their computer self-efficacy might be what do computers mean in their life, or what their perception about using it is. May be female students couldn't make any connection using computers in their career and this thinking in to the some extent may influence their attitude about computers. And because of this attitude toward computers, it caused female students to reduce anxiety level than male students.

Results related with students taking computer course and their computer self-efficacy, performance outcome, personal outcome, affective outcome and anxiety showed that computer self-efficacy, performance outcome, personal outcome and affective outcome of students who said they took computer course had higher scores than students who said they didn't, but this difference was not significant. Besides, anxiety scores of students who said they took computer course were higher than those who said they didn't. In that situation we need to question the effectiveness or reliability of computer course. Hence, students may have lack of interest to use computers, or they may not believe the importance and usefulness of computers in their educational environment. Accordingly, they didn't benefit from this course. Another important issue might be the shortage of equipment in terms of hardware and software. The findings of this study were supported by Aktag, 2015, which showed that physical education teachers had similar results after participating computer training programs. But according to Compeau, 1999, the more experience with computers reduces the level of anxiety and increases computer self-efficacy. Also Fasetiyan et al., 1996, found that computer training reduces the level of anxiety.

According to the result related to frequency of computer usage, it can be said that as computer usage frequency increases, computer self-efficacy level increases too Compeau et all, 1999.

When it was viewed form the computer usage time during weekdays, results showed us that students who stated they use computers more than 4 hours have the highest computer self-efficacy level. 362 students out of 452 stated they use computers between 30 min to more than 4 hours, it means students spend quite a time with computers. At the same time the more time students spend on computers their computer self-efficacy mean increased according to this.

Due to research model developed by Compeau and Higgins, 1995 as computer usage increases computer self-efficacy level is supposed to increase too.

When it was look at the computer usage during weekends, results show that as students spend more time on computers, their computer self-efficacy scores increased but this increasement was not significant. When it was look at the distribution of time period spending with computers, the number of students in each time period is close to each other. This distribution is different during weekdays, it means students spend less time during weekends when compare to weekdays. Findings of this study results supported by findings from Özçelik and Kurt, 2007; Sam et al., 2005; Aktag, 2015.

In this study, students GPA, computer course grade and computer self-efficacy level of students were searched and results showed that only significant correlation was found between computer course grade and GPA, and this correlation is low and negative way. It means students who have high GPA scores, receive lower grades from computer course. Contrary to findings of this study, Colak, 2013 found positive correlation between computer self-efficacy and computer course grade. Students who had more confident in their computer abilities were more successful in their computer classes.

\section{Conclusion and Recommendation}

1. There was no significant difference in computer self-efficacy, performance outcome, personal outcome, affective outcome of students according to gender. The only significant difference between male and female student was found in anxiety levels which female students had lower anxiety than male students. 
Aktağ, I., \& Tuzcuoğlu, S. (2016). Turkish students' computer self-efficacy from colleges of physical education and sports. International Journal of Human Sciences, 13(1), 1770-1779. doi:10.14687/ijhs.v13i1.3606

2. There was significant correlation in negative way among students' computer course grade and their GPA. There was no correlation among students' computer self-efficacy and computer course grade.

3. Students who took computer course had lower computer self-efficacy level than students who did not take computer course.

4. Computer self-efficacy level of students changed according to frequency of their computer usage, as students' usage frequency increases their computer self-efficacy level increases too.

5. Computer self-efficacy level of students changed significantly due to their computer usage during weekdays. The highest computer self-efficacy score belongs to students who spend more than 4 hours on computers.

6. Computer self-efficacy level of students didn't changed significantly due to their computer usage during weekends.

\section{References}

Aktag, I. (2015). Computer self-efficacy, computer anxiety, performance and personal outcomes of Turkish physical education teachers. Educational Research and Reviews, Vol. 10(3), 328-337.

Aktag, I. (2013). Changes in computer self-efficacy of pre-service teachers in physical education. International Journal of Academic Research, 5 (6), 169-177.

Bandura, A. (1997). Self-Efficacy: The exercise of control. W.H. Freeman and Company, New York.

Bandura, A. (1977). Social learning theory. Englewood Cliffs. Prentice Hall, NJ.

Compeau, D. R. and Higgins, C. A. (1995). Application of social cognitive theory to training for computer skills. MIS Q, 118-143.

Compeau, D. R., Higgins, C. A. and Huff, S. (1999). Social cognitive theory and individual reactions to computing technology: A longitudinal study. MIS Q, 23(2): 145-158.

Çolak, S. (2013). The relationship among computer self-efficacy scores, demographic characteristics, and grades in computer courses of students at the school of physical education and sports. Educational Research and Reviews, 8(8), 374-377.

Durndell, A. and Haag, Z. (2002). Computer self-efficacy, computer anxiety, attitudes toward the internet and reported experience with the Internet, by gender, in an Eastern European sample. Computers in Human Behavior, 18, 521-535.

Fasetiyan, S., Libii, J. and Hirschbuhl, J.( 1996). An in-service model for enhancing faculty computer self-efficacy. British Journal of Educational Technology, 27(3), 214-226.

İşman, A. and Çelikli, G. E. (2009). How does student ability and self-efficacy affect the usage of computer technology? Turkish Online Journal of Educational Technology, Vol 8 (1), 1303-6521.

Karsten, R., and Roth, R. (1998). Computer self-efficacy: A practical indicator of student computer competency in introductory IS courses. MIS Q.1 (3): 61-68.

Koçak-Usluel, Y. and Seferoğlu, S. (2003). Eğitim fakültelerindeki öğretim elemanlanının öz-yeterlik algiları. BTIE Poster sunumu, May, METU, Ankara.

Korobili, S., Togia, A. and Malliari, A. (2010). Computer anxiety and attitudes among undergraduate students in Greece. Computers in Human Behavior, 26, 399-405.

Pamuk, S. and Peker, D. (2009). Turkish pre-service science and mathematics teachers' computer related self-efficacies, attitudes and the relationship between these variables. Computers and Education, 53, 454-461. 
Aktağ, I., \& Tuzcuoğlu, S. (2016). Turkish students' computer self-efficacy from colleges of physical education and sports. International Journal of Human Sciences, 13(1), 1770-1779. doi:10.14687/ijhs.v13i1.3606

Papastergiou, M. (2010). Enhancing physical education and sport science students' self-efficacy and attitudes regarding information and communication technologies through a computer literacy course. Computers Education, 54(1) 298-308.

Pareskava, F., Bouta, H. and Papagianni, A. (2008). Individual characteristics and computer selfefficacy in secondary education teachers to integrate technology in educational practice. Computers and Education, 50, 1084-1091.

Saleh, H. K. (2008). Computer self-efficacy of university faculty in Lebanon. Educational Technology Research Development, 56:229-240.

Stuart, L., Mills, A. and Ramus, U. (2009). School leaders, ICT competence and championing innovations. Computers Education, 53: 733-741.

Şimşek, A. (2011). The relationship between computer anxiety and computer self-efficacy. Contemporary Educational Technology, 2(3), 177-187.

Teo,T. (2008). Pre-service teachers' attitude toward computer use: A Singapore survey. Australasian Journal of Educational Technology. 24(4), 413-424.

Tezci, E. (2011). Turkish primary school teachers' perceptions of school culture regarding ICT integration. Educational Technology Research Development, 53 (3):429-443.

Torkzadeh, G., Plfughoeft K. and Hall, L.(1999). Computer self-efficacy, training effectiveness and user attitudes: An empirical study. Behavior and Information Technology, 18, 299-309.

Ünlü, H., and Süel, E. (2014). Computer self-efficacy of prospective physical education teachers. Journal of Efficiency and Responsibility in Education and Science, Vol: 7, No: 2, 33-36.

Yalçınalp, S. (2005). A study of students' self-efficacy, performance and attitudes towards computers and internet in a computer literacy course at freshman. European Conference on Educational Research. 7-10 September. 